\title{
ANALISIS WACANA RETORIKA DAKWAH K.H. MUHAMMAD ARIFIN ILHAM
}

\author{
Bahroni \\ Dosen Komunikasi dan Penyiaran Islam IAIN Salatiga \\ bahronistainsala3@gmail.com
}

\begin{abstract}
Da'wah has become a very strategic object. Thus, the involvement of mass media plays important role in the activities, both printed and electronic. There are many well-known Da'i in Indonesia that have strong influence to the communities such as K.H. Muhammad Arifin Ilham (MAI). The study aims to demonstrate the grammatical structure and lexical cohesion of MAI's da'wah rhetoric. The data analysis consists of: (1) sorting the data based on the problem; (2) formulating the data units into each sequence in accordance with the possibility of their features; (3) interpreting the data values based on the problem; (4) evaluating the level of visibility and completeness of the data that linked to the range of problems. The structure of the grammatical cohesion of MAI's rhetoric includes reference, substitution, ellipsis and conjunction. The manifestation of MAI's lexical cohesion rhetoric comprises of repetition, synonym, antonym, hyponym, collocation, and equivalence.
\end{abstract}

Keywords: discourse analysis, da'wah rhetoric, mass media

\begin{abstract}
Abstrak
Dakwah merupakan hal yang sangat strategis. Oleh karena itu, aktivitas tersebut tidak luput dari liputan media massa, baik cetak maupun eletronik. Di antara da'i Indonesia yang sangat dikenal oleh masyarakat luas adalah K.H. Muhammad Arifin Ilham (MAI). Tujuan penelitian ini untuk mendeskripsikan wujud kohesi gramatikal dan leksikal retorika dakwah MAI. Adapun langkah analisis datanya sebagai berikut: (1) pengurutan data sesuai dengan masalahnya; (2) pembentukan satuan-satuan data dalam setiap urutannya sesuai dengan kemungkinan hubungan ciri kategorinya; (3) interpretasi nilai data sesuai dengan masalahnya; (4) evaluasi tingkat kelayaan dan kelengkapan data dikaitkan dengan rentang masalahnya. Wujud kohesi gramatikal retorika dakwah MAI mencakup referensi, substitusi, elipsis, dan konjungsi. Wujud kohesi leksikal retorika dakwah MAI mencakup repetisi, sinonimi, antonimi, hiponimi, kolokasi, dan ekuivalensi.
\end{abstract}

Kata kunci: analisis wacana, retorika dakwah, media massa 
INJECT (Interdisciplinary Journal of Communication), Vol.3, No.1, Juni 2018: h. 39-58

\section{Pendahuluan}

Siapakah yang lebih baik perkataannya daripada orang yang menyeru kepada Allah, mengerjakan amal yang shalih dan berkata: "Sesungguhnya aku termasuk orang-orang yang berserah diri." Dan tidaklah sama kebaikan dan kejahatan. Tolaklah (kejahatan itu) dengan cara yang lebih baik, maka tiba-tiba orang yang antara kamu dan antara dia ada permusuhan seolah-olah telah menjadi teman yang sangat setia. Sifat-sifat yang baik itu tidak dianugerahkan melainkan kepada orangorang yang sabar dan tidak dianugerahkan melainkan kepada orang-orang yang mempunyai keberuntungan yang besar (Qs. Surat Fushshilat:33-35).

Ayat tersebut merupakan bekal utama bagi para aktivis dakwah di jalan Allah (da'i), agar selalu semangat dan istiqamah, tidak pernah gentar dan getir, senantiasa menjalankan tugasnya dengan tenang, tidak emosional dan seterusnya. Ayat tersebut diletakkan setelah ayat sebelumnya di awal surat, Allah menggambarkan sikap orang-orang yang tidak mau menerima ajaran Allah. "Mereka mengatakan: hati kami tertutup, (maka kami tidak bisa menerima) apa yang kamu serukan kepadanya, pun telinga kami tersumbat, lebih dari itu di antara kami dan kamu ada dinding pemisah" (Qs. Surat Fushshilat:5). Dakwah di jalan Allah adalah kebutuhan pokok manusia. Tanpa dakwah manusia akan tersesat jalan, jauh dari tujuan yang diinginkan Allah. Para Rasul dan Nabi yang Allah pilih dalam setiap fase adalah dalam rangka untuk menjalankan dan menegakkan risalah dakwah ini(http://andri13ar.blogspot.co.id/p/ pentingnya-dakwah.html).

Salah satu kewajiban umat Islam adalah berdakwah. Sebagian ulama ada yang menyebut berdakwah itu hukumnya fardu kifayahatau kewajiban kolektif, sebagian lainnya menyatakan fardu ain atau kewajiban individual. Meskipun begitu, Rasulullah Muhammad selalu mengajarkan agar seorang muslim selalu menyeru pada jalan kebaikan dengan cara-cara yang baik. Dakwah berarti kegiatan yang bersifat menyeru, mengajak dan 
memanggil orang lain untuk beriman dan taat kepada Allah SWT, sesuai dengan garis akidah, syariat dan akhlak Islam. Secara bahasa, dakwah merupakan masdar (kata benda) dari kata kerja da'a yad'u yang artinya "panggilan", "seruan" atau "ajakan".

Ada beberapa metode dakwah yang bisa dilakukan seorang Muslim. Pertama, dakwah fardiah, yakni metode dakwah yang dilakukan seseorang kepada orang lain (satu orang) atau kepada beberapa orang dalam jumlah yang kecil dan terbatas. Kedua, dakwah ammah, yakni jenis dakwah yang dilakukan oleh seseorang dengan media lisan yang ditujukan kepada orang banyak dengan maksud menanamkan pengaruh kepada mereka. Media yang dipakai biasanya berbentuk khutbah (pidato). Selain itu juga dikenal istilah dakwah bi-al lisan, yakni penyampaian informasi atau pesan dakwah melalui lisan (ceramah atau komunikasi langsung antara subjek dan objek dakwah). Selain itu, Rasulullah juga mengajarkan umatnya untuk dakwah bi-al haal, yakni dakwah yang mengedepankan perbuatan nyata. Hal ini dimaksudkan agar si penerima dakwah (mad'u) mengikuti sang da'i. Berdakwah dengan perbuatan memiliki pengaruh yang besar pada mad'u (http://www.republika.co.id/-pentingnya-dakwah)

Secara sederhana dan penuh daya, dalam pandangan Suhandang (2014:13), Islam menekankan individualitas serta keunikan manusia. Allah memiliki ketetapan yang pasti mengenai takdir manusia sebagai kesatuan kehidupan. Konsekuensi dari pandangan terhadap manusia yang demikian itu, sebagai insan yang unik dan tidak mungkin dipilih dari makhluk lain, maka Allah memilih dan mempercayakan manusia sebagai penguasa di bumi.

Abbas Mahmud Al 'Aqad (1976:11) memberi makna karakteristik manusia menjadi empat jenis: (1) manusia adalah sejenis hewan yang pandai berbicara, (2) manusia merupakan hewan yang berkebudayaan menurut alamiahnya, (3) manusia merupakan ruh yang tinggi dan diturunkan dari langit ke bumi, dan (4) manusia adalah sejenis hewan yang maju. Definisidefinisi itulah yang paling populer dibanding definisi lain yang mencakup 
makna karakter manusia: (1) manusia memperoleh segi kelebihan akal (rasio), (2) manusia memperoleh segi interaksi kemasyarakatan, (3) tinjauan pengertian manusia atas sifatnya, merupakan gambaran cerita yang pernah terjadi pada diri Adam ketika ia memakan buah khuldi karena tipuan syetan, dan (4) kajian mengenai martabat manusia di antara macammacam makhluk hidup, sesuai dengan teori evolusi.

Penciptaan manusia menurut pandangan Islam merupakan pelaksanaan kehendak (iradah) Allah, sebagai pelaksana peraturan alam. Untuk mewujudkan kehendak tersebut, Allah memberi manusia sumber keistimewaan dan kekuatannya sekaligus sebagai pangkal kelebihan dan keutamaannya, yaitu menjadi suatu ciptaan Allah yang agung, tidak ada makhluk lain yang bisa menyamainya.

Pesan dalam dakwah, apapun bentuknya, pada hakikatnya merupakan hasil pengolahan manusia tersebut terhadap data, fakta, dan peristiwa yang terjadi di alam semesta ini, dan atas kehendak manusia itu sendiri disampaikannya kepada orang lain, dengan tujuan untuk memberitahu, menyampaikan informasi, mendidik, dan lain sebagainya, yang pada prinsipnya agar orang lain itu berubah sikap, sifat, pendapat, dan perilakunya sesuai dengan tuntunan Allah dan rasul-Nya.

Islam adalah agama dakwah artinya agama yang selalu mendorong pemeluknya untuk senantiasa aktif melakukan kegiatan dakwah, bahkan maju mundurnya umat Islam sangat bergantung dan berkaitan erat dengan kegiatan dakwah yang dilakukannya. Implikasi dari pernyataan Islam sebagai agama dakwah menuntutut umatnya agar selalu menyampaikan dakwah, karena kegiatan ini merupakan aktivitas yang tidak pernah usai selama kehidupan masih berlangsung dan akan terus melekat dalam situasi dan kondisi apa pun bentuk dan coraknya (Munir, 2003:5-6).

Dakwah dan aktivitas-aktivitas keagamaan Islam yang lain, menurut Pudiyono (2008:247) merupakan hal yang sangat strategis. Oleh karena itu, aktivitas-aktivitas tersebut tidak luput dari liputan media 
massa, baik cetak maupun eletronik, baik offline maupun online. Hal ini dibuktikan dengan banyaknya majalah, radio, televisi, dan situs-situs di internet yang khusus menyebarluaskan pesan-pesan dakwah, bahkan sebagian besar televisi nasional maupun daerah yang tidak khusus untuk berdakwah pun, secara periodik menayangkan acara dengan konten dakwah. Di antara da'i nasional yang aktivitas dakwahnya disebarluaskan oleh media massa adalah K.H. Muhammad Arifin Ilham.

\section{Rumusan Masalah}

Rumusan masalah dalam penelitian ini adalah (1) bagaimanakah wujud kohesi gramatikal retorika dakwah K. H. Muhammad Arifin Ilham? (2) bagaimanakah wujud kohesi leksikal retorika dakwah K. H. Muhammad Arifin Ilham? Adapun tujuan penelitian ini adalah untuk (1) mendeskripsikan dan menjelaskan wujud kohesi gramatikal retorika dakwah $\mathrm{K}$. H. Muhammad Arifin Ilham? (2) mendeskripsikan dan menjelaskan wujud kohesi leksikal retorika dakwah K. H. Muhammad Arifin Ilham?

\section{Analisis Wacana}

Analisis wacana merupakan disiplin ilmu yang berusaha mengkaji penggunaan bahasa yang nyata dalam tindak komunikasi. Dalam praktiknya, analisis wacana merupakan aktivitas menganalisis bahasa yang digunakan secara alamiah, baik dalam bentuk tulis maupun lisan. Penggunaan bahasa secara alamiah tersebut berarti penggunaan bahasa seperti dalam komunikasi sehari-hari (Rani dkk., 2006:9).

Dardjowidjojo dalam Mulyana (2005:1) menerangkan bahwa analisis wacana berkaitan dengan pemahaman tentang tindakan manusia yang dilakukan dengan bahasa (verbal) dan bukan bahasa (nonverbal). Hal ini menunjukkan, bahwa untuk memahami wacana dengan baik dan tepat, diperlukan bekal pengetahuan kebahasaan, dan bukan kebahasaan (umum). Sebagai objek kajian dan penelitian kebahasaan, wacana dapat 
diteliti dari berbagai segi. Analisis wacana mengkaji wacana baik dari segi internal maupun eksternalnya. Dari segi internal, wacana dikaji dari jenis, struktur, dan hubungan bagian-bagian wacana; sedangkan dari segi eksternal, wacana dikaji dari segi keterkaitan wacana itu dengan pembicara, hal yang dibicarakan dan mitra bicara.

\section{Retorika Dakwah}

Retorika atau dalam bahasa Inggris rhetoric berasal dari bahasa Latin rhetorica yang berarti ilmu bicara. Termasuk dalam cakupan pengertian retorika adalah seni berbicara, kemahiran dan kelancaran berbicara, kemampuan memproduksi gagasan, dan mensosialisasikannya sehingga mampu mempengaruhi audien (http://indramukhtaroji.blogspot.com/ retorika). Retotika bisa dimaknai sebagai seni berbicara atau kemampuan merangkai kata-kata dengan maksud agar pendengar mudah memahami makna pesan yang disampaikannya.

Sedangkan dakwah secara etimologis berasal dari bahasa Arab yang berarti panggilan, seruan, atau ajakan kepada sesuatu (Suminto, 1984:53). Adapun secara terminologis, dakwah adalah mengajak, membimbing, dan memimpin orang yang belum mengerti atau sesat jalannya dari agama yang benar untuk dialihkan ke jalan ketaatan kepada Allah, menyuruh orang berbuat baik dan melarang berbuat buruk agar mendapat kebahagiaan di dunia dan akhirat (Ba'alawi dalam Saputra, 2002:2).

Berdasarkan pengertian retorika dan dakwah di atas, maka retorika dakwah dapat diartikan sebagai ketrampilan menyampaikan ajaran Islam secara lisan guna memberikan pemahaman yang benar kepada kaum muslimin agar mereka dapat dengan mudah menerima seruan dakwah yang karenanya pemahaman dan prilakunya dapat berubah menjadi lebih Islami. Seorang da'i perlu mempelajari retorika dakwah, agar ceramahnya dapat berlangsung dengan baik, mencerahkan pikiran dan dan menyentuh hati jama'ah. Dengan demikian, di samping penguasaan konsepsi Islam 
dan pengamalannya, keberhasilan dakwah juga sangat ditentukan oleh kemampuan komunikasi antara sang da'i dengan jama'ah yang menjadi objek dakwah.

\section{Hakikat Dakwah}

Ditinjau dari segi bahasa, da'wah berarti: panggilan, seruan, atau ajakan. Bentuk perkataan tersebut dalam bahasa Arab disebut mashdar. Sedangkan bentuk $f{ }^{\prime}$ il atau kata kerjanya adalah da'a-yad'u yang berartti memanggil, menyeru, atau mengajak. Orang yang berdakwah biasa disebut dengan $d a$ ' $i$ dan orang yang menerima dakwa atau orang yang didakwahi disebut dengan mad'u (Saputra, 2011:1). Adapun secara istilah, dakwah diartikan upaya mengajak umat dengan cara bijaksana kepada jalan yang benar sesuai dengan perintah Allah untuk kemaslahatan di dunia dan akhirat (Omar, 1992:1).

Menurut Syaikh Ali Makhfudz bahwa dakwah Islam merupakan mendorong manusia agar berbuat kebaikan dan mengikuti petunjuk (hidayah), menyeru mereka berbuat kebaikan dan mencegah dari kemungkaran, agar mereka mendapat kebahagiaan di dunia dan akhirat (Munir, 2006:7). Mengacu pada definisi tersebut, dapat ditegaskan bahwa: (1) Dakwah menjadikan perilaku muslim dalam menjalankan Islam sebagai agama rahmatan lil alamin yang harus didakwahkan kepada seluruh manusia, yang prosesnya melibatkan unsur: $d a^{\prime} i$ (subjek), maaddah (materi), thoriqoh (metode), washilah (media), dan mad'u (objek) dalam mencapai maqashid (tujuan) dakwah yang melekat dengan tujuan islam yaitu mencapai kebahagiaan hidup di dunia dan akhirat; (2) Dakwah juga dapat dipahami dengan proses internalisasi, transformasi, transmisi, dan difusi ajaran Islam dalam kehidupan masyarakat; dan (3) Dakwah mengandung arti panggilan dari Allah dan Rasul-Nya untuk umat manusia agar percaya kepada ajaran Islam dan mewujudkan ajaran yang dipercayainya itu dalam segala kehidupannya (Saputra, 2011:2-3). 
INJECT (Interdisciplinary Journal of Communication), Vol.3, No.1, Juni 2018: h. 39-58

\section{Metode Penelitian}

Penelitian ini menggunakan pendekatan kualitatif-deskriptif, yakni bertujuan untuk mengungkapkan berbagai informasi kualitatif dengan pendeskripsian yang teliti dan penuh nuansa untuk menggambarkan secara cermat sifat-sifat suatu hal, keadaan, fenomena, dan tidak terbatas pada pengumpulan data, tetapi meliputi analisis dan interpretasi data tersebut (Sutopo, 2002:111). Data penelitian kebahasaan adalah fenomena lingual khusus yang berkaitan langsung dengan masalah penelitian (Sudaryanto, 2002:5-6).

Data penelitian ini berupa satuan-satuan lingual yang membentuk kohesi gramatikal dan leksikal ditambah dengan faktor-faktor situasi dan latar belakang sosiokultural yang terdapat di luar teks. Sumber data dalam penelitian berupa rekaman ceramah K. H. Muhammad Arifin Ilham yang tersimpan dalam kaset dan alat-alat penyimpan yang lain, termasuk yang terdapat di media online seperti Youtube, serta dokumen-dokumen yang memuat ceramahnya. Disamping itu, data juga akan digali dari responden yang diwawancarai mengenai tanggapannya yang terkait dengan sosok dan substansi pesan-pesan dakwahnya.

Langkah-langkah analisis data dalam penelitian ini adalah sebagai berikut: (1) pengurutan data sesuai dengan masalah yang akan dijawab; (2) pembentukan satuan-satuan data dalam setiap urutannya sesuai dengan kemungkinan hubungan ciri kategorinya; (3) interpretasi nilai data sesuai dengan masalah yang akan dijawab; (4) evaluasi tingkat kelayaan dan kelengkapan data dikaitkan dengan rentang masalahnya. Evaluasi ini juga menyangkut penafsiran validitas data bila dihubungkan dengan isi penjelasan yang diberikan. Berdasarkan hasil evaluasi ini dapat ditentukan perlu tidaknya mencari data baru. Berdasarkan hasil analisis, selanjutnya dilakukan pendeskripsian, yakni penjelasan secara sistematis tentang fakta tertentu yang dihasilkan berdasarkan konsep dan cara kerja yang telah ditetapkan (Aminuddin, 1995:67). 


\section{Wujud Kohesi Gramatikal Retorika Dakwah K. H. M. Arifin Ilham}

Wujud kohesi gramatikal dalam teks ceramah K. H. M. Arifin Ilham berikut ini bersumber dari https://www.youtube.com diakses tanggal 2 Desember 2015.

\section{Referensi}

Contoh kohesi gramatikal yang berupa referensi adalah sebagai berikut.

(1) Teman, kita butuh teman. Teman ada yang hanya sekedar teman. Boleh jadi kenalan, satu sekolah, almamater, teman hobi, teman partai, teman bisnis. Itu hanya teman biasa sebenarnya.

(2) Ada teman yang ada maunya. Lagi sukses banyak yang mendekati, seperti manisan banyak datang semut. Atau saat dia lagi perlu, dia lagi butuh kita, dia berteman memang ada maunya. Tapi tatkala kita susah atau dia tidak butuh, dia akan meninggalkan kita.

(3) Ada teman khianat. Ini teman yang menyakitkan. Baik di depan mata kita, memuji kita seakan dia selalu untuk kita. Sebenarnya tidak demikian.

(4) Inilah kerinduan kita, teman yang luar biasa. Siapa itu? Di depaan kita baik, di belakang kita baik. Bahkan dalam doanya ia selalu menyertakan kita, "Selamatkanlah hamba, selamatkan teman hamba." Ia bawa kita dalam do'anya. Ia memperhatikan kita dengan tulus. Kadang menasehati kita, menengok kita, memberi hadiah kepada kita. Lahir batin dia sayang kepada kita. Inilah teman sejati, inilah teman luar biasa, inilah teman dunia akhirat. Karena itu jangan salah pilih teman. Cari sahabat yang tulus, lahir batin dan itulah teman shalih. Teman dunia akhirat.

Pada data (1) tersebut, itu merupakan referensi yang menunjuk beberapa satuan lingual pada kalimat sebelumnya, yaitu kenalan, satu sekolah, almamater, teman hobi, teman partai, teman bisnis, data (2) empat pronomina persona ketiga tunggal yakni dia menunjuk pada satuan lingual teman yang ada maunya, pada data (3) ada dua referensi yakni ini 
dan dia yang keduanya menunjuk pada frasa teman khianat, dan data (4) itu, ia, dan dia menunjuk pada frasa teman yang luar biasa.

\section{Substitusi}

Contoh kohesi gramatikal yang berupa substitusi berikut ini bersumber dari www.youtube.com diakses pada tanggal 29 November 2015.

(5) Semuanya fana kecuali Allah yang baka, semuanya hancur kecuali Allah. Dan semuanya yang berjiwa pasti mati.

(6) Kita sudah menyaksikan dengan mata telanjang saat keluarga kita wafat, orang tua kita, atau mungkin di bawah umurnya dari kita, anak kita dan kita hampir setiap hari melewati kuburan, bukankah mereka tadinya hidup, bukankah tadinya bersama kita .

(7) Dunia ini hanya tempat menyebrangi jembatan, sekedar terminal, sekedar mampir, sekarang alam dunia, sebentar kita akan masuk alam kubur melalui pintu alam sakarotul maut.

(8) Mati laksana pintu setiap mahluknya pasti melewati one by one datang kepada siapapun, datang pada yang miskin, datang juga pada yang kaya, datang pada orang tua, datang pula pada yang muda.

(9) Siapa pun yang ingin meninggal khusnul khotimah hidupkan sunansunah nabi Muhammad SAW sebagai langkah terbaik menghadapi kematian di antaranya tahajjud hamba Allah yang sering sholat malam dijamin meninggal dalam keadaan khusnul khotimah dengarkan!

Pada data (5) tersebut, satuan lingual fana disubstitusi dengan satuan lingual hancur dan mati, data (6) satuan lingual hidup disubstitusi dengan satuan lingual bersama kita, data (7) satuan lingual tempat menyebrangi jembatan disubstitusi dengan satuan lingual sekedar terminal dan sekedar mampir, data (8) satuan lingual siapapun disubstitusi dengan satuan lingual yang miskin, yang kaya, orang tua, dan yang muda, dan pada data (9) satuan lingual tahajjuddisubstitusi dengan satuan lingual sholat malam. 


\section{Elipsis}

Contoh kohesi gramatikal yang berupa elipsis berikut ini bersumber dari daritemanuntukteman.blogspot.co.id/2009/07/khutbah-jumattahajud.html

(10) Sungguh terbukti bahwa maqaman mahmudan 'kedudukan terpuji' diraih oleh umat Islam. Dua pertiga bumi dikuasai (ø).

(11) Betapa banyak kelompok yang sedikit, tetapi berkualitas (mukminin) mengalahkan kelompok yang banyak, tetapi sekadar kuantitas (kafirun, munafiqun, fasiqun, musyrikun, zhalimun) dengan izin Allah (QS Al-Baqarah: 249). Perhatikanlah kata izin Allah (ø).

(12) Alam semesta ini dalam iradat dan kodrat-Nya (QS Yasin: 82). Mengadulah pada-Nya pada waktu yang Ia minta untuk mengadu padanya di tengah malam. Rintihan batindan tangisan sukma (ø) benar-benar didengar dan diperkenankan oleh-Nya.

(13) Penikmat tahajud hanyalah hamba pilihan (ø). Tidak semua Muslim terpanggil melakukannya. Buktinya, semua kita bisa bangun malam, tetapi belum tentu mau shalat malam.

(14) Apakah sama hamba-Ku yang bangun shalat malam yang mengharapkan rida- $\mathrm{Ku}$, rahmat- $\mathrm{Ku}$, ampunan-Ku dengan mereka yang lelap dalam peraduan tidur. Apakah samahamba-Ku yang cerdas dengan yang tidak (ø).

Pada data (10) yang dielipskan satuan lingual umat Islam, data (11) yang dielipskan satuan lingual dalam ayat Al-Quran tersebut, data (12) yang dielipskan satuan lingual orang-orang yang bertahajud, data (13) yang dielipskan satuan lingual Allah, dan pada data (14) yang dielipskan satuan lingual cerdas.

\section{Konjungsi}

Contoh kohesi gramatikal yang berupa konjungsi berikut bersumber dari http://www.thoriqoh.com/2015/06/tausiah-ust-arifin-ilhamsesegar-telaga.html. 
(15) Kebahagiaan hidup di dunia ini bermula dari merasakan halaawatul iimaan (manisnya iman). Dan, halaawatul iimaan adalah buah dari al-mujaahadah fii thaa'atillah (usaha sungguh-sungguh untuk melaksanakan ketaatan kepada Allah).

(16) Surga terlalu mahal untuk diperoleh dengan dengan ibadah yang hanya 60 sampai 70 tahun usia hidup kita, meski banyak orang yang usia hidupnya kurang dari itu, dan usia yang digunakan untuk beribadah pun tidak mencapai separuhnya. Sementara nikmat yang Allah berikan kepada kita tidak terhitung dengan jumlah angka angka yang dibuat untuk urusan duniawi. Akan tetapi, Allah mencintai kita semua. Karena rahmat dan kasih sayang-Nya itulah, Dia memberikan rasa cinta dalam hati kita. Perasaan cinta pada keimanan dan menjadikannya terasa nikmat dan indah bagi orang orang yang beriman.

(17) Diumpamakan juga seperti anak kecil yang diajak rekreasi oleh orangtuanya. Dia akan merasa gembira ketika orangtuanya menjanjikan hal itu. Dia akan lebih gembira lagi ketika ia dan orangtuanya mulai bersiap-siap untuk berangkat ke tempatitu. Puncak kegembiraannya adalah pada saat ia sampai ke tempat tujuan. Begitu juga seorang hamba yang beribadah kepada Allah SWT. Dia akan melaksanakan ibadahnya dengan hati, khusyuk dan nikmat. Puncak kenikmatan beribadahnya dirasakan pada saat menjelang kematian. Dia akan merasakan kebahagiaan, karena itulah pintu pertemuannya dengan Allah SWT, Dzat yang selalu diibadahinya dengan segenap perasaan tunduk dan cinta selama hidupnya di dunia.

(18) Subhanallah, ingatlah bahwa orang orang yang beriman akan tetap berkumpul bersama keluarga mereka yang beriman di akhirat nanti. Sementara orang orang yang tidak beriman, keluarga mereka akan terpisah dan bercerai berai. Sungguh kehidupan di dunia adalah cerminan dari kehidupan akhirat. Jika di dunia kita hidup sukses dan bahagia dalam ketaatan kepada Allah, maka dia akhiratpun kita akan menjadi 
orang yang sukses dan bahagia dibawah naungan ridha Allah SWT.

(19) Perasaan cinta pada keimanan dan menjadikannya terasa nikmat dan indah bagi orang orang yang beriman. Oleh karena itu, semua kenikmatan yang Allah beri kepada kita, baik yang ada di dalam diri kita seperti hati,akal, panca indra, maupun diluar diri kita, yang ada di seluruh alam semesta, semuanya adalah fasilitas yang harus dipergunakan untuk beribadah kepada Allah SWT, sehingga kita bisa menjadi "abdan syakuuran" (hamba yang bersyukur).

Pada data (15) terdapat konjungsi dan untuk merangkai kalimat sebelumnya dengan kalimat sesudahnya. Konjungsi ini digunakan untuk menambah keterangan yang terdapat pada kalimat sebelumnya sehingga gagasannya semakin jelas. Pada data (16) terdapat konjungsi akan tetapi yang berfungsi untuk mempertentangkan gagasan yang terdapat pada kalimatkalimat sebelumnya dengan gagasan pada kalimat-kalimat sesudahnya. Pada data (17) terdapat dua konjungsi begitu juga yang berfungsi untuk menambah penjelasan kalimat-kalimat sebelumnya. Pada data (18) terdapat konjungsi subhanallah dan sementara. Yang pertama merupakan ungkapan bahasa Arab yang berarti Mahasuci Allah, yang fungsinya ialah untuk memperdalam makna pada kalimat sebelumnya dengan pernyataan sesudahnya. Yang kedua berfungsi untuk membedakan antara gagasan pada kalimat-kalimat sebelumnya dengan gagasan pada kalimat-kalimat sesudahnya. Adapun pada data (19) terdapat konjungsi oleh karena itu yang berfungsi untuk menyimpulkan pernyataan pada kalimat sebelumnya dengan penegasan yang termuat pada kalimat-kalimat sesudahnya.

\section{Wujud Kohesi Leksikal Retorika Dakwah K. H. Muhammad Arifin Ilham}

Kohesi leksikal tidak berkaitan dengan hubungan gramatikal dan hububungan sematik. Kohesi leksikan ini hanya berkaitan dengan hubungan yang didasarkan pada pemakaian kata. Terdapat sejumlah 
peranti kohesi leksikal untuk mewujudkan keututuhan suatu wacana, yaitu (1) repetisi (pengulangan), (2) sinonimi (persamaan kata), (3) antonimi (lawan kata), (4) hiponimi (hubungan atas bawah), (5) kolokasi (sanding kata), dan (6) ekuivalensi (kesepadanan).

\section{Repetisi}

Contoh-contoh kohesi leksikal jenis repetisi yang digunakan oleh Ustadz Arifin Ilham dalam teks ceramahnya dapat dilihat pada contohcontoh berikut.

(20) Islam agama yang sempurna universal mencakup semua aspek kehidupan. Islam memaparkan dengan jelas, visi misi kehidupan sesaat di dunia ini.

(21) Hamba telah ridho kepada Engkau Rab yang mengatur hamba, hamba ridho terhadap Islam sebagai sistem manhaj kehidupan hamba, dan hamba ridlo nabi Muhammad SAW sebagai uswah hasanah dalam kehidupan hamba.

(22) Subuh-subuh sholat, setiap dhuhur sholat, ashar sore sholat, mau gelap magrib sholat kemudian dekat lagi waktunya sholat lagi isya'. Bahkan ada sholat dhuha, sholat tahajud, ada istikharah, ada hajah, ada tasbih, ada qobliyah, ada ba'diyah.

(23) Itu mukjizat, itu huda, petunjuk untuk kita, untuk menyelamatkan hidup kita dunia akherat.

(24) Syirik, syirik itu bukan tidak beriman kepada Allah. Dia beriman kepada Allah tapi juga beriman kepada selain Allah. Dia percaya kepada Allah, tapi juga percaya kepada selain Allah. Dia sembah Allah, tapi juga sembah selain Allah. Dia percaya pada Allah tapi percaya pada keris, percaya pada jimat, percaya pada dukun.

Pada data (20) terdapat jenis repetisi anáfora yakni berwujud perulangan kata pertama pada tiap baris atau kalimat berikutnya yaitu berupa kata Islam. Pada data (21) terdapat jenis repetisi epanalepsis yakni 
repetisi yang berwujud kata terakhir dari baris, klausa, atau kalimat, mengulang kata pertama, yaitu berupa pengulangan kata hamba. Pada data (22) terdapat jenis repetisi epizeuksis yakni repetisi yang bersifat langsung, artinya kata yang dipentingkan diulang beberapa kali berturutturut, yaitu berupa pengulangan kata sholat. Pada data (23) terdapat jenis repetisi campuran anafora dan epistrofa yaitu berupa pengulangan kata itu di awal baris dan kita di akhir baris. Pada data (24) terdapat jenis repetisi epizeuksis yakni repetisi yang bersifat langsung, artinya kata yang dipentingkan diulang beberapa kali berturut-turut, yaitu berupa pengulangan kata syirik. Di samping itu, juga terdapat repetisi epistrofa yakni repitisi yang berwujud perulangan kata atau frasa pada akhir baris atau kalimat berurutan yaitu berupa pengulangan kata Allah.

\section{Sinonimi}

Kohesi leksikal jenis ini banyak digunakan oleh ustadz Arifin Ilham dalam teks ceramahnya, sebagaimana dapat dilihat pada contohcontoh berikut.

(25) Ini tauhid, ini iman, ini aqidah.

(26) Kemudian yang baru-baru kemarin, selamat tahun baru. Perayaan mubadzir, perayaan sia-sia. Rasulullah SAW sudah bersabda "hari raya yang kalian banggakan adalah idul fitri dan idul adha."

(27) Perlihatkanlah, tampilkanlah, demonstrasikanlah dirimu sebagai seorang muslim.

(28) Saudaraku, politik harfiahnya adalah siasat atau strategi untuk meraih kekuasaan demi suatu tujuan.

Dalam konteks kalimat pada data (25) kata tauhid bersinonim dengan aqidah. Dalam konteks kalimat pada data (26) kata mubadzir bersinonim bersinonim dengan sia-sia. Dalam konteks kalimat pada data (27) tiga kata perlihatkanlah, tampilkanlah, demonstrasikanlah adalah bersinonim. Dalam konteks kalimat pada data (28) kata siasat bersinonim dengan kata strategi. 
INJECT (Interdisciplinary Journal of Communication), Vol.3, No.1, Juni 2018: h. 39-58

\section{Antonimi}

Kohesi leksikal jenis ini banyak digunakan oleh ustadz Arifin Ilham dalam teks ceramahnya, sebagaimana dapat dilihat pada contohcontoh berikut.

(29) Karena itu, hitam putih politik tergantung siapa aktornya. Cenderung pragmatis dan inkonsistensi. "Tiada lawan kawan yang abadi kecuali kepentingan abadi."

(30) Dulu sangat rendah hati dan sederhana pada sahabat-sahabatnya, tetapi setelah berkuasa yang ada keangkuhan.

(31) Semuanya fana kecuali Allah yang baka, semuanya hancur kecuali Allah. Dan semuanya yang berjiwa pasti mati. Bahkan pada akhirnya malaikat maut yang paling terakhir mati juga mati, kecuali Allah Maha Hidup, yang menghidupkan Al-Mu'it yang mematikan.

(32) Mati laksana pintu setiap mahluknya pasti melewati one by one datang kepada siapapun, datang pada yang miskin, datang juga pada yang kaya, datang pada orang tua, datang pula pada yang muda.

Pada data (29) kata hitam berantonin atau beroposisi putih. Oposisi antara hitam dengan putih merupakan oposisi kutub. Pada data (30) idiom rendah hati beroposisi dengan kata keangkuhan. Oposisi antara rendah hati dengan keangkuhan juga merupakan oposisi kutub. Pada data (31) kata fana beroposisi dengan baka. Oposisi antara fana dengan baka merupakan oposisi mutlak.Selain itu, ada juga oposisi antara hidup dengan mati dan antara menghidupkan dengan mematikan. Kedua pasang oposisi ini juga bersifat mutlak. Pada data (32) juga terdapat jenis oposisi kutub, yakni kata kaya beroposisi dengan miskin dan kata tua beroposisi dengan muda.

\section{Hiponimi}

Kohesi leksikal jenis ini banyak digunakan oleh ustadz Arifin Ilham dalam teks ceramahnya, sebagaimana dapat dilihat pada contohcontoh berikut. 
(33) Ampuni seluruh dosa kami. Dosa besar dosa kecil. Sengaja tidak sengaja. Terang-terangan maupun yang kami sembunyikan dengan rapi selama ini, yang sebenarnya tidak ada yang tersembunyi di mataMu. Ampuni dosa kami yang dilakukan dengan bercanda, apalagi sungguh-sungguh.

(34) Hanya soal waktu kita akan meninggalkan dunia ini, akan meninggalkan keluarga kita selama-lamanya. Dan setiap detik yang kita lalui apalagi jam, apalagi hari, apalagi tahun tidak akan pernah berulang. Siapa yang bisa kita tunda lagi waktu yang sudah berlalu.

(35) Mati laksana pintu setiap mahluknya pasti melewati one by one datang kepada siapapun, datang pada yang miskin, datang juga pada yang kaya, datang pada orang tua, datang pula pada yang muda.

Pada data (33) satuan lingual dosa besar, dosa kecil, sengaja, tidak sengaja, terang-terangan, kami sembunyikan berhiponim terhadap frasaseluruh dosa (hipernim). Pada data (34) satuan lingual detik, jam, hari, dan tahun berhiponim terhadap kata waktu (hipernim). Pada data (35) satuan lingual miskin, kaya, tua, dan muda berhiponim terhadap kata siapapun (hipernim).

\section{Kolokasi}

Kohesi leksikal jenis ini banyak digunakan oleh ustadz Arifin Ilham dalam teks ceramahnya, sebagaimana dapat dilihat pada contohcontoh berikut.

(36) Kita sudah menyaksikan dengan mata telanjang saat keluarga kita wafat, orang tua kita, atau mungkin di bawah umurnya dari kita, anak kita dan kita hampir setiap hari melewati kuburan, bukankah mereka tadinya hidup, bukankah tadinya bersama kita.

(37) Sungguh semua para Rasul, anbia, aulia, dan ulama pilihan adalah penggemar, bahkan penik mattahajud. Inilah hidangan hidayah terlezat bagi hamba-hamba Allah.

(38) Sesungguhnya, bangun di tengah malam lebih tepat untuk menjadi khusyuk. Bacaan kala itu sungguh amat berkesan. Thibannafs, kata 
Nabi, jiwanya hidup bercahaya. Semakin jelaslah bahwa tahajud adalah ibadah bagi pemburu keridaan-Nya. Karena itu, raihlah kemuliaan malam dan kenikmatan hidup pada-Nya. Untaian tasbih, gerak tubuh, tetesan air mata 'kan menjadi kebanggaan Allah di hadapan para malaikat-Nya.

(39) Oleh karena itu, semua kenikmatan yang Allah beri kepada kita, baik yang ada di dalam diri kita seperti hati, akal, panca indra, maupun di luar diri kita, yang ada di seluruh alam semesta, semuanya adalah fasilitas yang harus dipergunakan untuk beribadah kepada Allah SWT, sehingga kita bisa menjadi "abdan syakuuran" (hamba yang bersyukur).

Pada data (36) kolokasi atau sanding kata terjadi pada keluarga, orang tua, dan anak yang merupakan lingkungan famili. Data (37) kolokasi terjadi pada rasul, anbia, aulia, dan ulamayang merupakan lingkungan status orang-orang mulia yang tidak pada Allah. Data (38) kolokasi terjadi pada tengah malam, khusyuk, tahajud, ibadah, untaian tasbih, dan tetesan air mata yang merupakan lingkungan qiyam al-lail. Adapun data (39) kolokasi terjadi pada kenikmatan, hati, akal, panca indra, alam semesta, dan abdan syakuuran (hamba yang bersyukur)yang merupakan lingkungan mensyukuri karunia Allah.

\section{Ekuivalensi}

Kohesi leksikal jenis ini banyak digunakan oleh ustadz Arifin Ilham dalam teks ceramahnya, sebagaimana dapat dilihat pada contohcontoh berikut.

(40) Kau bangga dengan Islammu, maka Allah banggakan kalian pada malaikat dan di akherat nanti.

(41) Bahkan pada akhirnya malaikat maut yang paling terakhir mati juga mati, kecuali Allah Maha hidup, yang menghidupkan, Al-Mumit yang mematikan, sebelum kehadiran kita sudah dijadwalkan, jadwal 
kematian kita, setiap kita bahkan dipanjangkan umur, dilemahkan fisik, usia berkurang, berarti semakin hari, jam, menit, detik, makin dekat dengan jadwal kematian.

(42) Dia akan lebih gembira lagi ketika ia dan orangtuanya mulai bersiapsiap untuk berangkat ke tempat itu. Puncak kegembiraannya adalah pada saat ia sampai ke tempat tujuan.

(43) Begitu juga seorang hamba yang beribadah kepada Allah SWT. Dia akan melaksanakan ibadahnya dengan hati, khusyuk dan nikmat. Puncak kenikmatan beribadahnya dirasakan pada saat menjelang kematian. Dia akan merasakan kebahagiaan, karena itulah pintu pertemuannya dengan Allah SWT, Dzat yang selalu diibadahinya dengan segenap perasaan tunduk dan cinta selama hidupnya di dunia.

(44) Mereka yang sukses di akhirat dimulai dari kesuksesan mereka menjalani hidup di dunia adalah dengan menjadi hamba yang bertakwa.

Pada data (40) ekuivalensi sebagai kohesi leksikal tampak pada paradigma bangga dan banggakan; (41) pada paradigma hidup, menghidupkan jadwal, dan dijadwalkan; data (42) pada paradigma gembira dan kegembiraan; data data (43) pada paradigma beribadah, ibadahnya, beribadahnya dan diibadahinya; adapun data (44) pada paradigma sukses dan kesuksesan.

\section{Daftar Pustaka}

Abbas Mahmud, Al-Aqad. al-Mar'ah fi al-Qur'an. Dar al-Kutub al-Arabi. tth

Aminuddin. 1995. Stilistika Pengantar Memahami Bahasa dalam Karya Sastra. Semarang: IKIP Press.

An-Nabiry, Fathul Bahri. 2008. Meniti Jalan Dakwah Bekal Perjuangan Para Da'i. Jakarta: Amzah.

Ilham, Muhammad Arifin. 2003. Hakikat Zikir Jalan Taat Menuju Allah. Jakarta: Intuisi Press. 
Mulyana. 2005. Kajian Wacana: Teori, Metode dan Aplikasi Prinsip-Prinsip Analisis Wacana. Yogyakarta: Tiara Wacana.

Munir, M. 2003. Metode Dakwah. Jakarta: Kencana. . 2006. Metode Dakwah, Jakarta: Kencana.

Omar, Toha Tjahja. 1992. Ilmu Da'wah. Jakarta: Widjaya.

Rani, Abdul, dan Bustanul Arifin, dkk. 2006. Analisis Wacana Sebuah Kajian Bahasa dalam Pemakaian. Malang: Bayumedia Publishing.

Saputra, Wahidin. 2011. Pengantar Ilmu Dakwah. Jakarta: Raja Grafindo Persada.

Subroto, D. Edi. 1992. Pengantar Metode Penelitian Linguistik Struktural. Surakarta: Sebelas Maret University Press.

Sudaryanto. 2002. Metode dan Aneka Teknik Analisis Bahasa. Yogyakarta:

Duta Wacana University Press.

Suhandang, Kustadi. 2014. Strategi Dakwah Penerapan Strategi Komunikasi dalam Dakwah. Bandung: Remaja Rosdakarya.

Sumarlam. 2008. Teori dan Praktik Analisis Wacana. Surakarta: Pustaka Cakra.

Suminto, Aqib. 1984. Problematika Dakwah. Jakarta: Pustaka Panjimas. Sutopo, H.B. 2002. Metodologi Penelitian Kualitatif Dasar Teori dan Terapannya dalam Penelitian. Surakarta: Sebelas Maret University Press.

Yusuf, M. Yunan. 2016. Dakwah Rasulullah Sejarah dan Problematika. Jakarta: Kencana.

\section{Internet}

http://andri13ar.blogspot.co.id/p/pentingnya-dakwah.html http://indramukhtaroji.blogspot.com/2014/10/retorika-dalam-dakwah, http://www.republika.co.id/-pentingnya-dakwah 